\title{
Trophic cascade in a seaweed-epifauna-fish food chain
}

\author{
Emma M. Newcombe ${ }^{1,2, *}$, Richard B. Taylor ${ }^{1}$ \\ ${ }^{1}$ Leigh Marine Laboratory, University of Auckland, PO Box 349, Warkworth 0941, New Zealand \\ ${ }^{2}$ Present address: Instituto Antártico Chileno, Plaza Muñoz Gamero 1055, Punta Arenas, Chile
}

\begin{abstract}
Trophic cascades have been described in many ecosystems where predation on a herbivore affects biomass or productivity of primary producers. While trophic cascades can be particularly strong on rocky reefs, the majority of studies are restricted to sea urchin herbivores despite the presence of numerous other grazers. The present study examines the potential for predation by small fishes on New Zealand rocky reefs to suppress small invertebrate grazers (epifauna) living on brown seaweeds, with cascading effects on host seaweeds and their epiphytic algae. A trophic cascade was identified in experiments run in outdoor mesocosms. When epifaunal densities were reduced either artificially or by fish predation, seaweeds were more fouled, but less damaged, than where epifaunal populations flourished. These experimental findings were not fully consistent with patterns observed at field sites with varying fish densities. Variation in epifaunal taxonomic structure and seaweed palatability potentially dampened the cascading effect of fish predation on epifauna. Trophic cascades with non-urchin herbivores warrant further study, with a combination of laboratory and field work necessary to understand systems in which herbivores are difficult to manipulate.
\end{abstract}

KEY WORDS: Marine trophic cascade $\cdot$ Epifauna $\cdot$ Ecklonia radiata $\cdot$ Notolabrus celidotus

\section{INTRODUCTION}

Trophic cascades in benthic marine habitats are among the strongest known for any ecosystem, and have been described for saltmarshes (Silliman \& Bertness 2002), seagrass beds (Moksnes et al. 2008) and reefs (Estes \& Duggins 1995). Most studies on reefs focus on a food chain comprised of seaweeds, herbivorous sea urchins, and predatory fishes, lobsters or sea otters (Shurin et al. 2002). While the emphasis on sea urchins is understandable due to the striking effects they often have on seaweed communities (Harrold \& Pearse 1987), other herbivores have been comparatively neglected. This is particularly true for mobile epifauna, the small (<20 mm) crustaceans, gastropods and polychaetes that live inconspicuously on seaweeds and other vegetation (Brawley 1992). The impact of herbivorous epifauna ('mesograzers'; Hay et al. 1987) on their host seaweeds can be negative where the grazers are feeding on the host's tissues directly, or positive where they are consuming fouling epiphytes
(Duffy 1990). Some epifaunal taxa are capable of grazing their host seaweeds to destruction in the field (Tegner \& Dayton 1987, Graham 2002) or in culture (Smit et al. 2003), but this has rarely been observed in nature, which is usually attributed to the suppression of mesograzer populations by small predatory fishes (Kennelly 1983, Dayton et al. 1984, Korpinen et al. 2007, Davenport \& Anderson 2007). Few studies, however, have provided direct evidence for this posited fish-mesograzer-seaweed cascade (but see Duffy \& Hay 2000, Davenport \& Anderson 2007, Korpinen et al. 2007).

Experimenting on mobile epifauna in the field is technically difficult because many taxa are highly mobile (e.g. Taylor 1998), so they rapidly recolonise experimentally defaunated seaweeds (Poore 2005), and their emigration is likely to swamp any impact of fish exclusion on the scale of conventional experiments (Edgar \& Aoki 1993).

We therefore investigated the dynamics of the seaweed-epifauna-fish food chain by manipulating densities of epifauna and fishes in outdoor tanks (in north- 
eastern New Zealand). The results of these experiments were then compared with patterns observed at local field sites varying greatly in densities of small predatory fishes. Spatial differences in the palatability of seaweeds to epifauna were also measured as a possible explanation for variation in levels of epifaunal grazing observed in the field (e.g. Taylor et al. 2003).

\section{MATERIALS AND METHODS}

Study organisms. The small wrasse Notolabrus celidotus (Bloch \& Schneider, 1801) is common on shallow rocky reefs throughout New Zealand (Jones 1980). Individuals are closely associated with seaweeds and feed on small crustaceans until they reach about $120 \mathrm{~mm}$ in length, when they switch to larger prey (Jones 1984). Epifaunal populations are abundant and diverse in northeastern New Zealand (Taylor \& Cole 1994), although they appear to be depressed at sites with high $N$. celidotus densities (Taylor 1991). Seaweed forests in this area are generally dominated by the laminarian Ecklonia radiata, although the fucaleans Carpophyllum flexuosum and C. maschalocarpum are also common (Choat \& Schiel 1982, Shears \& Babcock 2004).

Mesocosms. To test the effect of progressive trophic levels of the focal system on the levels below, 12 tanks, each $1.8 \mathrm{~m}$ in diameter and $0.63 \mathrm{~m}$ deep (volume $\sim 1.3 \mathrm{~m}^{3}$ ), were set up outdoors at the Leigh Marine Laboratory in northeastern New Zealand. Flowthrough seawater filtered to $0.5 \mathrm{~mm}$ was supplied to each tank via a 601 dump bucket to produce the water movement necessary for seaweed health (authors' pers. obs.). Shade cloths intercepting $70 \%$ of light were placed over each tank to prevent photodamage to the seaweeds. In the tanks, 3 treatments were each replicated 4 times: (1) 'Seaweed' = seaweed with epifaunal populations removed with the insecticide carbaryl (Duffy \& Hay 2000); (2) 'Epifauna' = seaweed with epifaunal populations intact; and (3) 'Fish' = seaweed, epifauna and fish. Seaweeds were collected locally (in plastic bags to retain epifaunal populations) and immediately added to tanks in December 2003 (austral summer). Ecklonia radiata ( 8 plants) and Carpophyllum flexuosum and C. maschalocarpum (3 each) were tied to a frame at the bottom of each tank. These densities represented natural seaweed densities on nearby reefs. Tanks were then left for 2 mo to ensure that epifaunal populations were well established.

When experimental conditions were first set up, epifauna were removed from the Seaweed treatment by removing plants from tanks and soaking them for $1 \mathrm{~h}$ in a $1.5 \mu \mathrm{l} \mathrm{l}^{-1}$ carbaryl solution (slightly stronger than that used by Duffy \& Hay 2000). This method proved to be impractical, due to recolonisation of seaweed by epi- fauna living on the tank walls or dislodged while removing the plants. For the second treatment, therefore, carbaryl was added directly to the tank. The water flow into all tanks in the row to be treated was turned off, and carbaryl was added into the treatment tank to achieve a concentration of $1 \mu l \mathrm{l}^{-1}$. Water flow was restored after 90 min. Duffy \& Hay (2000) used the insecticide carbaryl in their similar experimental setup, and found no noticeable effects on the growth or survival of any of the focal organisms except for the (targeted) crustacean epifauna. Wild-caught Notolabrus celidotus were held in aquaria and fed on mussels for several weeks prior to setup of experimental conditions, when 4 individuals of 45 to $60 \mathrm{~mm}$ standard length (SL) were randomly assigned to each tank in the Fish treatment. The resultant density of 1.6 ind. $\mathrm{m}^{-2}$ was within the range of values measured in the field (see 'Results'). Tanks were scrubbed regularly to minimise fouling and periodically cleaned by siphoning. During the experiment, 1 replicate of each of the treatments Seaweed and Epifauna was lost due to an accidental switching of treatment. Experiments were terminated after $\sim 90 \mathrm{~d}$.

Before removal from the tanks, seaweeds were scored for health. Damage was identified as small holes in the middle of the fronds of Ecklonia radiata. Grazing damage on Carpophyllum spp. was not easily quantified, and therefore only weight was used as a measure of damage for this taxon. The most and least damaged E. radiata and the cleanest and most fouled of each seaweed taxon from any tank was identified and photographed. The least and most affected examples across all tanks were scored 0 and 4 respectively. Intermediate examples were then identified and given corresponding ratings, and each plant was scored accordingly. Indices were considered more appropriate than percent cover estimates, as the patchiness of damage and fouling, and the convoluted form of the $E$. radiata made percent cover estimates unreliable.

Plants (and associated epifauna) were collected without holdfasts in plastic bags with $0.2 \mathrm{~mm}$ mesh drainholes, with all Ecklonia radiata plants from a tank in 1 bag and all Carpophyllum spp. plants in another. The 2 species of Carpophyllum were not distinguished as many plants were too damaged by grazing to be identified. Epifauna were rinsed off the seaweeds by washing in freshwater (Taylor \& Cole 1994) and preserved in formalin for at least 1 mo. Samples were rinsed on a sieve (1 mm mesh; epifauna $>1 \mathrm{~mm}$ being more likely to be consumed by fish [Edgar \& Shaw 1995] and most likely to affect seaweed health [Mancinelli \& Rossi 2001]), and all crustaceans were counted.

Field. To test whether the patterns observed in the mesocosm experiments were reflected in the field, seaweed, epifauna and fish populations were monitored 
over time at sites with high and low fish densities (Jones 1983). At Waterfall Reef and Matatuahu Point, northeastern New Zealand, fish were counted (on 3 separate occasions per season) within $2 \times 5 \mathrm{~m}$ transects ( $\mathrm{n}=4$ to 6 ) (this transect size was appropriate due to the small size and high abundances of these fish) and epifaunal populations and seaweed health measures were quantified, in summer, autumn, and spring 2005. The latter 2 seasons showed the greatest variation in fish density (E. M. Newcombe unpubl. data).

Five haphazardly selected Ecklonia radiata were collected from each site. Plants were scored for fouling and damage with an index based on percent cover estimates of selected fronds in an attempt to produce a finer-scale measure of plant health, while avoiding the inaccuracy expected if whole plants were scored.

Five fronds of length $>100 \mathrm{~mm}$ were scored. One was haphazardly selected from each of the lower, middle and upper parts of the primary lamina. The whole plant was then searched to find the fronds most and least affected by fouling and damage. Percent cover of fouling on the most heavily fouled side of blades was scored between 0 and $100 \%$. Damage was scored between 0 and $20 \%$ (when $>20 \%$ of the frond was eaten away the plant began to disintegrate). Plants were scored for fouling underwater as fouling tended to get dislodged when the plant was collected. Damage was estimated in the laboratory after the plants had been cleaned. Estimates were made with reference to percent cover diagrams to ensure accuracy across sites.

Epifauna were preserved in formalin and later processed as for those from the mesocosm experiments, except that common gammarid amphipod and isopod taxa were identified to genus (or species). This allowed for identification of herbivorous taxa (from references in Appendix E of Taylor \& Steinberg 2005).

Seaweed palatability. In an attempt to understand why grazing damage in the field did not more closely match results from the mesocosm experiments, we compared the palatabilities of seaweed from sites with high (Matatuahu Point) and low (Waterfall Reef) fish densities. We measured rates at which the common gammarid amphipod Aora typica consumed the kelp Ecklonia radiata in choice and no-choice assays. Within each replicate the same 2 fronds (1 from each site) were used in all relevant treatments (all fronds were taken from different plants at $\sim 4 \mathrm{~m}$ depth). Amphipods and $50 \mathrm{mg}$ pieces of seaweed were placed in $250 \mathrm{ml}$ of seawater in 20 replicates of 4 treatments (Control, both seaweeds; Choice, both seaweeds, 12 amphipods per replicate; Matatuahu Point seaweed, 6 amphipods; Waterfall Reef seaweed, 6 amphipods per replicate).

A small glass rod divided the 2 pieces of seaweed in each of the Control and Choice treatments to enable their subsequent identification. Containers were covered with dark plastic to facilitate amphipod feeding, and a partial water change was made on the second day. On the third day seaweed pieces were blotted dry and reweighed. Surviving amphipods were counted, and consumption for each replicate calculated as:

$$
\mathrm{CA}=\left(\mathrm{W}_{\mathrm{i}}-\mathrm{W}_{\mathrm{f}}\right) \times \mathrm{Cf} \times \mathrm{n}_{\mathrm{a}}{ }^{-1} \times \mathrm{d}^{-1}
$$

where $\mathrm{CA}=$ consumption of individual amphipods per day, $\mathrm{W}_{\mathrm{i}}=$ initial seaweed weight, $\mathrm{W}_{\mathrm{f}}=$ final seaweed weight, $\mathrm{Cf}=$ correction factor from control, $\mathrm{n}_{\mathrm{a}}=$ average number of live amphipods (averaged throughout assay), and $d=$ number of days.

Data analysis. Mesocosm data were log-transformed where necessary to meet the assumption of homogeneity of variance. One-way ANOVAs were performed with 'seaweed', 'epifauna' and 'fish' levels in the factor 'treatment'. Tukey's tests $(\alpha=0.05)$ were run when appropriate to identify where differences lay. Many of the plants were damaged and fragile; therefore when measuring plant size it was necessary to use only the largest 4 (Carpophyllum spp.) or 6 (Ecklonia radiata) plants to ensure that whole plants, not fragments, were being measured.

\section{RESULTS}

\section{Mesocosms}

In the mesocosm experiment (Fig. 1), fish reduced densities of crustacean epifauna to an average of $7 \%$ of their predator-free densities on Ecklonia radiata, and to $20 \%$ of their predator-free densities on Carpophyllum spp. (Fig. 1a,b). Log of total epifaunal abundance (for epifauna $>1 \mathrm{~mm}$ mesh) was significantly higher in the Epifauna treatment than the Fish treatment for $E$. radiata (1-way ANOVA followed by Tukey's test: $\mathrm{n}=3$ to $4, F=10.5, \mathrm{p}=0.008$, fish = algae $<$ epifauna), and Carpophyllum spp. (>1 mm mesh: 1-way ANOVA followed by Tukey's test: $\mathrm{n}=3$ to $4, F=4.9$, $\mathrm{p}=0.046$, no treatments significantly different). Epifaunal populations in the Seaweed treatment would have fluctuated greatly between carbaryl treatments and recovery. Final density was therefore not a good indicator of densities across the experiment in this treatment, so significant results were not expected.

Epifaunal populations not subject to fish predation in turn reduced biomass (i.e. increased damage) of seaweeds to $74 \%$ (Ecklonia radiata) and $21 \%$ (Carpophyllum spp.) of epifauna-free seaweed biomass. A trophic cascade was apparent, as in the presence of fish predation, seaweed attained $87 \%$ (E. radiata) and $74 \%$ (Carpophyllum spp., Fig. 2) of epifauna-free seaweed biomass (Fig. 1 c,d) (E. radiata: 1-way ANOVA: $\mathrm{n}=3$ to 4 , 

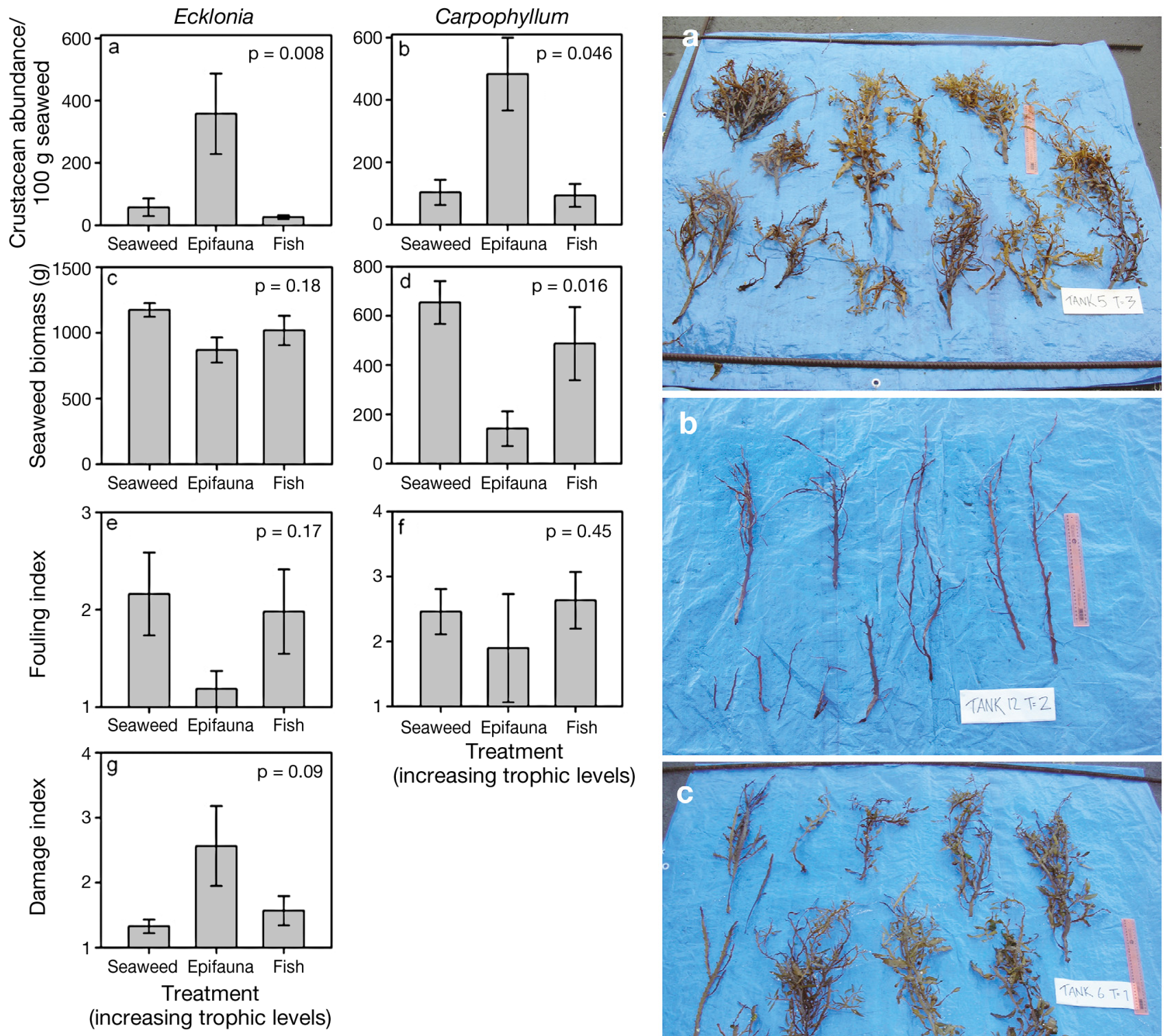

(increasing trophic levels)

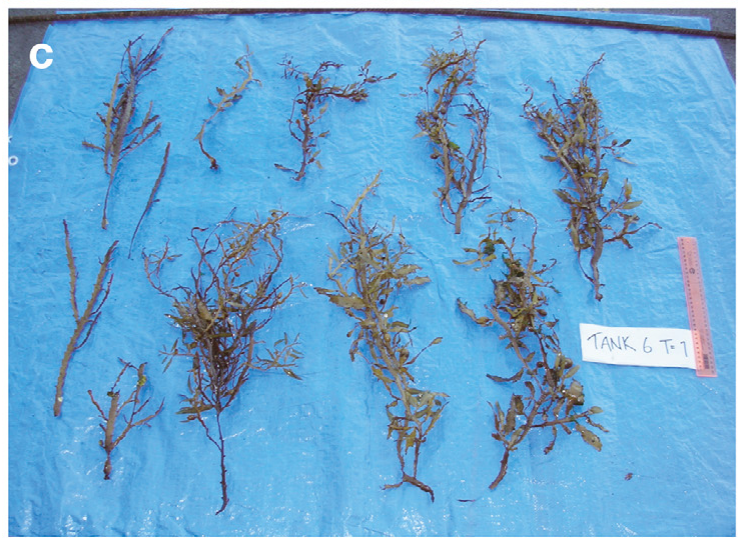

Fig. 1. Ecklonia radiata and Carpophyllum spp. (a,b) Density of crustacean epifauna (0.5 to $4.0 \mathrm{~mm}$ mesh size); (c,d) seaweed biomass; (e,f) epiphytic fouling; and (g) frond damage (E. radiata only) where progressive levels of a seaweed-epifauna-fish food chain were added to outdoor mesocosms (i.e. Epifauna and Fish treatments include trophic level(s) beneath). Fouling indices were produced by scoring all plants on a scale between 1 (least fouled) and 5 (most fouled). Error bars represent mean $\pm 1 \mathrm{SE}$

Fig. 2. Carpophyllum spp. Representative plants from (a) Seaweed, (b) Epifauna and (c) Fish treatments in a mesocosm experiment. Epifauna and Fish treatments include trophic levels beneath

$F=2.2, \mathrm{p}=0.18 ;$ Carpophyllum spp.: 1-way ANOVA followed by Tukey's test: $\mathrm{n}=3$ to $4, F=8.0, \mathrm{p}=0.016$, algae $=$ fish $>$ epifauna). The degree of fouling also changed with the addition of more trophic levels; in the presence of predator-free epifaunal populations, the seaweed fouling index score for E. radiata was $16 \%$ of that on epifauna-free seaweeds and $19 \%$ of that in tanks with fish (Fig. 1e). Similarly, on Carpophyllum spp. in the presence of predator-free epifaunal popula- tions, the seaweed fouling index score was $61 \%$ of that on epifauna-free seaweeds and $55 \%$ of that in tanks with fish (Fig. 1f) (E. radiata: 1-way nested ANOVA: $\mathrm{n}=3$ to $4, F=2.3$, $\mathrm{p}_{\text {treatment }}=0.17$; Carpophyllum spp.: 1-way nested ANOVA: $F_{\text {treatment }}=0.9, \mathrm{p}_{\text {treatment }}=0.45$ ). The damage index score on $E$. radiata was $64 \%$ higher in the Epifauna treatment than in either other treatment (1-way nested ANOVA: $\mathrm{n}=3$ to $4, F_{\text {treatment }}=3.5$, $\left.\mathrm{p}_{\text {treatment }}=0.09\right)($ Fig. $1 \mathrm{~g})$. 

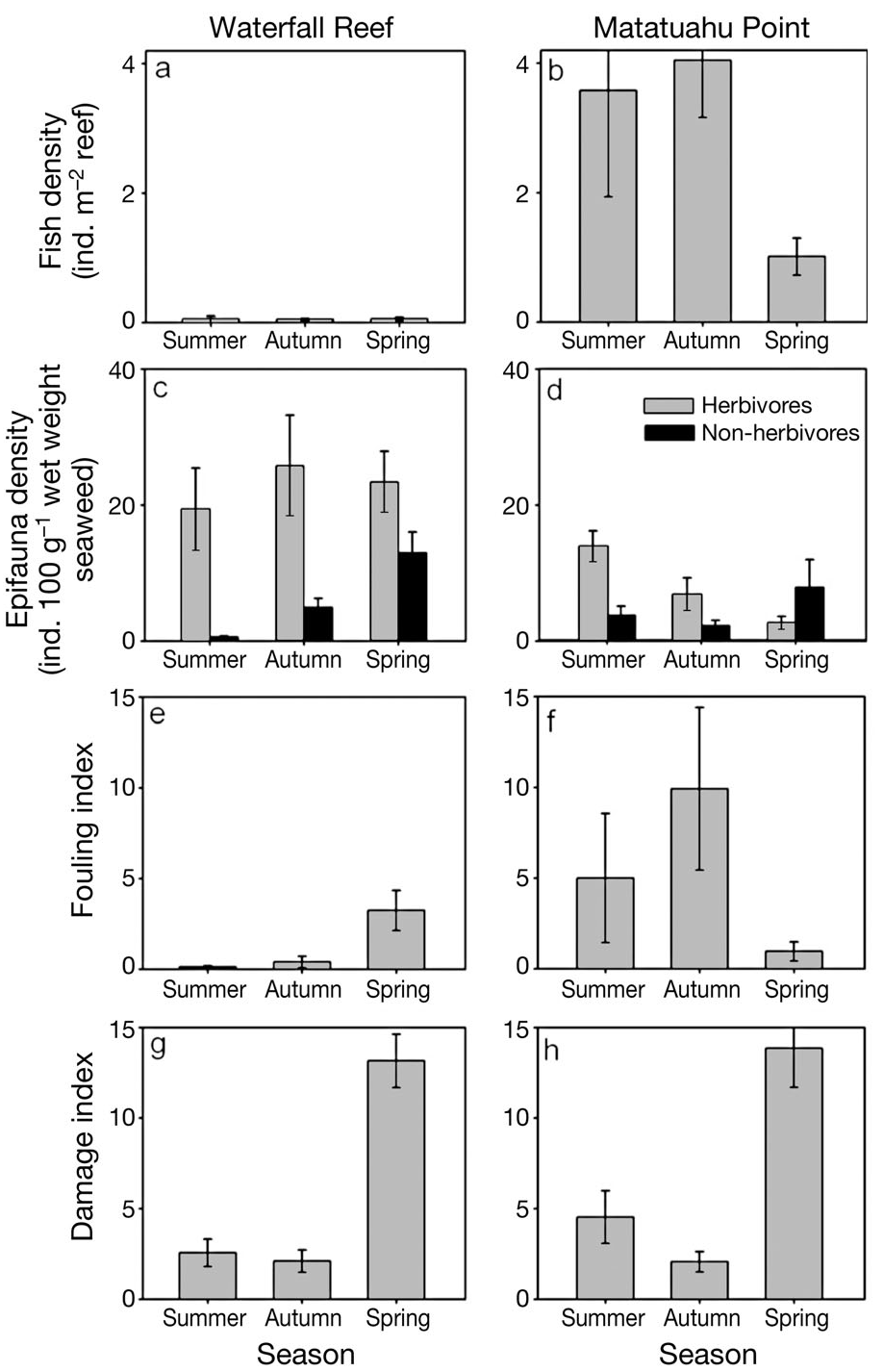

Fig. 3. $(\mathrm{a}, \mathrm{b})$ Fish (Notolabrus celidotus) density, $(\mathrm{c}, \mathrm{d})$ epifaunal density, and indices of $(\mathrm{e}, \mathrm{f})$ fouling and $(\mathrm{g}, \mathrm{h})$ damage for the kelp Ecklonia radiata at sites with low (Waterfall Reef) and high (Matatuahu Point) fish densities over 3 seasons. Indices are generated from percent cover estimates from fronds. Error bars represent mean $\pm 1 \mathrm{SE}$

\section{Field}

Based on findings from the mesocosm experiments, we expected to find greater levels of seaweed damage and lower levels of fouling at a site with low fish density (high epifaunal abundance) than at a site where relatively abundant fishes depleted epifauna. Furthermore, as the fish populations at Matatuahu Point declined over the winter we expected to see a recovery of epifaunal populations, and a corresponding increase in plant damage and decrease in fouling.

Epifauna showed no recovery after the winter fish population decline at Matatuahu Point; in fact both

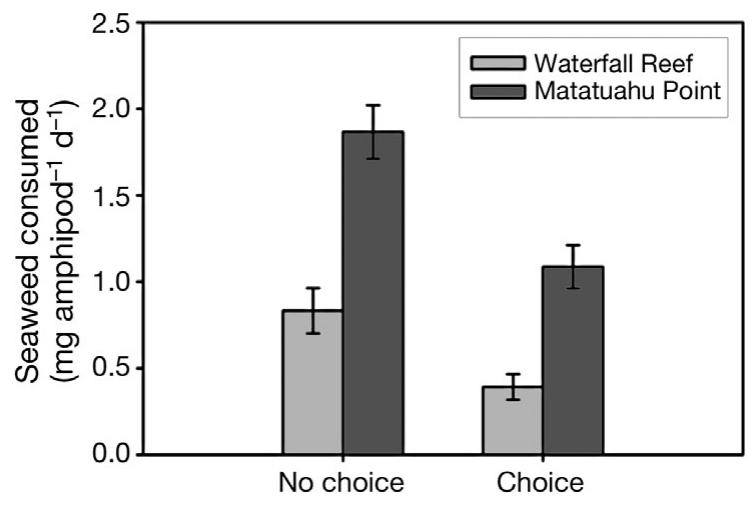

Fig. 4. Amount of the kelp Ecklonia radiata from Waterfall Reef and Matatuahu Point consumed by the gammarid amphipod Aora typica in laboratory experiments, in choice and no-choice assays. Error bars represent mean $\pm 1 \mathrm{SE}$

sites showed a decline in epifaunal densities from autumn to spring (Fig. 3a,b). Herbivorous species made up a greater proportion of the epifaunal population at Matatuahu Point than at Waterfall Reef; however, herbivores were still more abundant at the latter site (Fig. $3 c, d)$. The index of fouling was over 10 times higher at Matatuahu Point (high fish density, low epifaunal density) than at Waterfall Reef (as predicted) in 2 out of 3 seasons; however, in the third season this switched, and the index at Waterfall Reef was the higher by a factor of $>3$ (Fig. 3e,f). The types of fouling differed between sites; at Waterfall Reef fouling on Ecklonia radiata was almost always small red epiphytic algae, while at Matatuahu Point it was largely more fragile diatoms with small amounts of hydroids (E. M. Newcombe pers. obs.). Also counter to predictions, damage indices were nearly identical between sites (Fig. 3g,h). The largest difference was in summer when algae at Matatuahu Point (low epifaunal densities) registered an index almost twice as high as at Waterfall Reef.

\section{Seaweed palatability}

The amphipod Aora typica consumed over twice as much tissue of the kelp Ecklonia radiata from the site with high fish densities in both choice and no-choice assays (Fig. 4) ( $t$-test: no choice: $t=5.100, \mathrm{df}=35$; choice: $t=4.791, \mathrm{df}=29, \mathrm{p}<0.0001$ for both comparisons, $\mathrm{n}=19$ ).

\section{DISCUSSION}

The fish-epifauna-seaweed trophic cascade revealed by the mesocosm experiment presented here generalises the findings of Duffy \& Hay (2000) from eastern 
North America to rocky reefs in New Zealand, and is consistent with the field experiments of Davenport \& Anderson (2007). Effects of epifauna on seaweed as demonstrated by our mesocosm experiments were consistent with results of previous studies, in that the epifauna can have both positive and negative effects on seaweeds (Duffy 1990, Mancinelli \& Rossi 2001, Kamermans et al. 2002).

Seaweeds exposed to epifaunal densities that were reduced either artificially or via fish predation were larger but more heavily fouled than seaweeds with uncontrolled epifaunal populations. This 'trophic cascade' - where the health or biomass of a primary producer changes in the presence of a herbivore, but switches back with the addition of a predator-is reported in a range of ecosystems (Shurin et al. 2002).

Based on the results from the mesocosm experiments we predicted that field sites and sampling seasons with higher fish densities and less abundant epifaunal populations would have (1) higher levels of fouling on host seaweeds, and (2) lower levels of damage to host seaweeds. The failure of field-based measures of seaweed health to fully support predictions with respect to variation in epifaunal abundance is unlikely to be because the epifauna have no effect, given the mesocosm results presented here and results from other studies (Duffy \& Hay 2000, Mancinelli \& Rossi 2001, Davenport \& Anderson 2007, Korpinen et al. 2007).

Both spatial and temporal variation in fouling occurred in the field, while the substantial temporal variation in damage measures was similar between sites. In contrast to the mesocosm results, high epifaunal densities were not associated with high damage to host seaweeds. This can potentially be explained by both taxonomic differences in epifaunal communities between sites, and by variation in the palatability of the seaweed. Filter-feeding ischyrocerid amphipods (Nair \& Anger 1979, Sotka et al. 1999) dominated the amphipod fauna at Waterfall Reef (low fish densities) in all 3 seasons studied. The dominance of such non-herbivorous epifauna and the lower palatability of plants could also explain the lack of damage to the plants despite higher crustacean densities. Although most taxa occurred at both sites, at Matatuahu Point (high fish densities), the dominance of the isopod Plakarthrium typicum and the amphipod Aora typica (both of which cause damage to fronds of Ecklonia radiata; Newcombe 2009), and the greater palatability of the E. radiata are consistent with the high levels of damage found.

To better understand the seaweed-epifauna-fish trophic cascade in natural systems, seaweed palatability and epifaunal community structure (crustacean and non-crustacean) will be important considerations. The association of high fish (Notolabrus celidotus) densities with sheltered sites (Denny 2005, Newcombe 2009) would need to be further investigated, as would variation in plant palatability with shelter.

Fish densities at Matatuahu Point fell in the winter (E. M. Newcombe unpubl.), but may still have been high enough to suppress epifaunal populations, which did not recover in spring. The seasonal changes in damage and fouling did not appear to be related to changes in epifaunal density. It is possible that seasonal changes in water temperature could affect the feeding activity of epifauna. Also, it is likely that algal health was affected by seasonal variation in growth and tissue quality of seaweeds, growth of fouling organisms, and, particularly in the case of Matatuahu Point, in the frequency of wave action of sufficient strength to affect the delicate fouling found at this site, which may have a far greater short-term effect than the epifauna.

Ecklonia radiata was chosen for study as it is the most abundant and widely distributed seaweed in the study area. Because the primary meristem of E. radiata occurs at the base of the large and thick primary lamina (Mann \& Kirkman 1981), it is somewhat protected from grazing damage, unlike that of the fucalean Carpophyllum spp. and many other taxa where the meristem is apical (Clayton 1984) and thus more exposed to herbivores. This is consistent with the differences seen in the effect of biomass in the mesocosm experiments, where, despite a lesser reduction of epifauna, biomass was more strongly affected in Carpophyllum spp. than E. radiata.

A number of trophic cascades with epifaunal grazers have been at least partially documented on a small scale in natural systems where fish exclusion caused depletion of benthic communities. For example, mobile epifauna reduced algal biomass in damselfish territories when damselfish were excluded (Zeller 1988), and Kennelly (1983) found exclusion of fish caused a population explosion of small invertebrates and a reduction in algal growth. It is probable that many or most field sites have sufficiently high densities of small predatory fish to control epifaunal populations. A 'pre-existing' depletion of epifauna by fish may account for the lack of effect on seaweed health following the experimental reduction of epifauna in the field (as found by Poore et al. 2009).

Here we have shown that epifaunal communities in northeastern New Zealand have the potential to cause substantial damage to host seaweeds. In mesocosms, a trophic cascade occurred where fish predation on epifauna released seaweeds from the effects of epifaunal grazing. We were able to identify a number of factors that apparently caused this effect to be dampened in the field, and future research could take into account covariation of these factors in replicated field sites and across multiple seaweed species. For small and highly 
mobile epifauna, laboratory-based experiments can provide an important controllable environment to complement field-based studies.

Acknowledgements. This project was funded by a Marsden Fast-Start grant (UOA216) to R.B.T. and a University of Auckland Doctoral Scholarship to E.M.N. Thanks to staff, students and volunteers at the Leigh Marine Laboratory, in particular S. Crutchley, for help with diving and maintenance of experiments.

\section{LITERATURE CITED}

Brawley SH (1992) Mesoherbivores. In: John DM, Hawkins SJ, Price JH (eds) Plant-animal interactions in the marine benthos. Clarendon Press, Oxford, p 235-263

Choat JH, Schiel DR (1982) Patterns of distribution and abundance of large brown algae and invertebrate herbivores in subtidal regions of northern New Zealand. J Exp Mar Biol Ecol 60:129-162

Clayton MN (1984) Evolution of the Phaeophyta with particular reference to the Fucales. Prog Phycol Res 3:11-46

Davenport AC, Anderson TW (2007) Positive indirect effects of reef fishes on kelp performance: the importance of mesograzers. Ecology 88:1548-1561

Dayton PK, Currie V, Gerrodette T, Keller BD, Rosenthal R, Ven Tresca D (1984) Patch dynamics and stability of some California kelp communities. Ecol Monogr 54:253-290

Denny CM (2005) Distribution and abundance of labrids in northeastern New Zealand: the relationship between depth, exposure and pectoral fin aspect ratio. Environ Biol Fishes 72:33-43

Duffy JE (1990) Amphipods on seaweeds: partners or pests? Oecologia 83:267-276

Duffy JE, Hay ME (2000) Strong impacts of grazing amphipods on the organization of a benthic community. Ecol Monogr 70:237-263

Edgar GJ, Aoki M (1993) Resource limitation and fish predation: their importance to mobile epifauna associated with Japanese Sargassum. Oecologia 95:122-133

Edgar GJ, Shaw C (1995) The production and trophic ecology of shallow-water fish assemblages in southern Australia. II. Diets of fishes and trophic relationships between fishes and benthos at Western Port, Victoria. J Exp Mar Biol Ecol 194:83-106

Estes JA, Duggins DO (1995) Sea otters and kelp forests in Alaska: generality and variation in a community ecological paradigm. Ecol Monogr 65:75-100

Graham MH (2002) Prolonged reproductive consequences of short-term biomass loss in seaweeds. Mar Biol 140: 901-911

Harrold C, Pearse JS (1987) The ecological role of echinoderms in kelp forests. Echinoderm Stud 2:137-233

$>$ Hay ME, Duffy JE, Pfister CA, Fenical W (1987) Chemical defense against different marine herbivores: are amphipods insect equivalents? Ecology 68:1567-1580

Jones GP (1980) Growth and reproduction in the protogynous hermaphrodite Pseudolabrus celidotus (Pisces: Labridae) in New Zealand. Copeia 1980:660-675

Jones GP (1983) Relationship between density and behaviour in juvenile Pseudolabrus celidotus (Pisces: Labridae). Anim Behav 31:729-735

> Jones GP (1984) The influence of habitat and behavioural interactions on the local distribution of the wrasse, Pseudolabrus celidotus. Environ Biol Fishes 10:43-58

Kamermans P, Malta EJ, Verschuure JM, Schrijvers L, Lentz

Editorial responsibility: Hans Heinrich Janssen,

Oldendorf/Luhe, Germany
LF, Lien ATA (2002) Effect of grazing by isopods and amphipods on growth of Ulva spp. (Chlorophyta). Aquat Ecol 36:425-433

> Kennelly SJ (1983) An experimental approach to the study of factors affecting algal colonization in a sublittoral kelp forest. J Exp Mar Biol Ecol 68:257-276

$>$ Korpinen S, Jormalainen V, Honkanen T (2007) Bottom-up and cascading top-down control of macroalgae along a depth gradient. J Exp Mar Biol Ecol 343:52-63

Mancinelli G, Rossi L (2001) Indirect, size-dependent effects of crustacean mesograzers on the Rhodophyta Gracilaria verrucosa (Hudson) Papenfuss: evidence from a short-term study in the Lesina Lagoon (Italy). Mar Biol 138: 1163-1173

> Mann KH, Kirkman H (1981) Biomass method for measuring productivity of Ecklonia radiata with the potential for adaptation to other large brown algae. Aust J Mar Freshw Res 32:297-304

> Moksnes PO, Gullström M, Tryman K, Baden S (2008) Trophic cascades in a temperate seagrass community. Oikos 117: 763-777

> Nair KKC, Anger K (1979) Experimental studies on the life cycle of Jassa falcata (Crustacea, Amphipoda). Helgol Wiss Meeresunters 32:444-452

Newcombe EM (2009) The nature and implications of variation in the structure of a seaweed-epifauna-fish food chain. PhD thesis, University of Auckland

> Poore AGB (2005) Scales of dispersal among hosts in a herbivorous marine amphipod. Austral Ecol 30:219-228

> Poore AGB, Campbell AH, Steinberg PD (2009) Natural densities of mesograzers fail to limit growth of macroalgae or their epiphytes in a temperate algal bed. J Ecol 97:164-175

Shears NT, Babcock RC (2004) Community composition and structure of shallow subtidal reefs in northeastern New Zealand. Sci Conserv 245:1-65

Shurin JB, Borer ET, Seabloom EW, Anderson K and others (2002) A cross-ecosystem comparison of the strength of trophic cascades. Ecol Lett 5:785-791

Silliman BR, Bertness MD (2002) A trophic cascade regulates salt marsh primary production. Proc Natl Acad Sci USA 99:10500-10505

Smit AJ, Fourie AM, Robertson BL, du Preez DR (2003) Control of the herbivorous isopod, Paridotea reticulata, in Gracilaria gracilis tank cultures. Aquaculture 217: 385-393

Sotka EE, Hay ME, Thomas JD (1999) Host-plant specialization by a non-herbivorous amphipod: advantages for the amphipod and costs for the seaweed. Oecologia 118: 471-482

Taylor RB (1991) Effects of Notolabrus celidotus (Labridae) predation on motile macroalgal epifauna. MSc thesis, University of Auckland

Taylor RB (1998) Short-term dynamics of a seaweed epifaunal assemblage. J Exp Mar Biol Ecol 227:67-82

Taylor RB, Cole RG (1994) Mobile epifauna on subtidal brown seaweeds in northeastern New Zealand. Mar Ecol Prog Ser 115:271-282

Taylor RB, Steinberg PD (2005) Host use by Australasian seaweed mesograzers in relation to feeding preferences of larger grazers. Ecology 86:2955-2967

Taylor RB, Lindquist N, Kubanek J, Hay ME (2003) Intraspecific variation in palatability and defensive chemistry of brown seaweeds: effects on herbivore fitness. Oecologia 136:412-423

> Tegner MJ, Dayton PK (1987) El Niño effects on southern California kelp forest communities. Adv Ecol Res 17:243-279

Zeller DC (1988) Short-term effects of territoriality of a tropical damselfish and experimental exclusion of large fishes on invertebrates in algal turfs. Mar Ecol Prog Ser 44:85-93 